\title{
Does Regional Affiliation Influence Employees' Perception of Tourism Policy in Cultural Tourism?
}

\author{
Aleksa Š. VučetićA ${ }^{A}$ Jovo AteljevićB, Tatjana Pivac ${ }^{C}$, Sanela Kovačević PejakovićD \\ Received: November 2017 | Accepted: December 2017 \\ DOI: 10.5937/turizam21-16718
}

\begin{abstract}
The study tries to explain the influence of regional affiliation on employees' perception of tourism policy in the sector of cultural tourism. The main aim is to explore whether there is a difference between regional affiliations of employees and employees' perception of tourism policy in the sector of cultural tourism in Montenegro. The survey was conducted using the interviewing, and the main statistical procedures were factor analysis and multivariate analysis of variance. Research outcome is a significant difference between employees in the northern and the coastal region of Montenegro, in the employees' perception of the importance of measures and activities of tourism policy in the sector of cultural tourism. However, that difference could not significantly influence tourism policymaking process and the quality of specific tourism policy, which is intended for development of cultural tourism in Montenegro. Most of the significant differences depend on measures and activities, which do not directly influence the growth and development of cultural tourism that way. The study is inspired by the Erasmus+ CULTURWB project.
\end{abstract}

Keywords: Regional affiliation of employees, measures and activities of tourism policy, cultural tourism, Montenegro.

\section{Introduction}

Cultural tourism is special interest tourism or niche tourism (Lee, Bai, 2016; McKercher, 2005; Novelli, 2005), i.e., selective tourism (Boniface, Cooper, 2009; Čorak, Mikačić, 2006; Luković, 2013; Vučetić, 2017). Today, cultural tourism is one of the most known and most wanted types of selective tourism on the global tourism market. That is why, many organizations in the tourism sector and tourist destinations on mezzo-, micro- and macro-level try to develop this selective tourism type. Cultural tourism can generate great economic, social and, specifically,

\footnotetext{
A University of Montenegro, Faculty of Tourism and Hospitality, Kotor, Montenegro; aleksavucetic@gmail.com

B University of Banja Luka, Faculty of Economics, Banja Luka, Bosnia and Herzegovina; jovo.ateljevic@ef.unibl.org

c University of Novi Sad, Faculty of Science - Department of Geography and Hotel Management, Serbia; tatjana_pivac@yahoo.com

D University of Montenegro, Faculty of Philology, Niksic, Montenegro; sanelap@ac.me
} 
the political effect for all participants who have an offer of cultural tourism in a tourism destination.

Today, cultural tourism destination can be a city (Athens, Moscow, New York, Kotor), region (Catalonia, Emilia-Romagna), country (Austria, Czech Republic) and even a continent (Europe). Montenegro is a relatively new destination for cultural tourism, and it is the well-recognized destination of cultural tourism (together with Dubrovnik County) in the European zone.

Montenegro has a great benefit from cultural tourism development. The majority of sameday visitors are visitors in the field of cultural tourism who are visiting Kotor in Boka Kotorska bay and Cetinje, but also other old towns in the coastal region such as Herceg Novi, Perast, Budva, Bar, and Ulcinj. The fact is that cultural tourism is the main factor in tourism development in the coastal and the central region of Montenegro.

Cultural tourism is a respectable factor of tourism sustainability of destination product of Montenegro (Pasinović, 2006; VRCG, 2008; Vuleković, 2009). This type of selective tourism has a positive influence on the ecological, economic, social and cultural sustainability of tourism sub-product in the coastal, central and northern region of Montenegro. In that context, cultural tourism is one of the main factors of political stability in above-quoted regions.

Montenegro has had developing tourism policy since the 1960s, and it has continued today. In the quoted period, there were many measures and activities of tourism policy in the tourism sector, but the very small number in the sector of cultural tourism. Selective tourism types were developing on the government's organizational way only from the 2000 . This study is a contribution to research in the field of influence of tourism policy on cultural tourism development, specifically in the field of influence of measures and activities of tourism policy on the growth and development of cultural tourism in Montenegro.

\section{Literature review}

Tourism policy is a strong tool for governments who try to develop the tourism sector in the country. It is a very important tool for tourism development on local (Camisón, Forés, 2015; Castillo-Manzano, 2010; Thomas, Thomas, 2006), regional (Hai-ling et al., 2011; Jeuring, Haartsen, 2016; Matias et al., 2009), national (Adamczyk, 2005; Horng, Tsai, 2010; Ranjan Debata et al., 2013), and supranational or international level (Edgell et al., 2008; Estol, Font, 2016). Contemporary good knowns supranational tourism policy is the European Union tourism policy (Andriotis, 2004; Hall et al., 2006; Moufakkir, Burns, 2012).

Tourism policymakers should create an optimal set of measures and activities of tourism policy on all planning levels, which will accelerate the tourism development of total tourism product or specific tourism product. Thereby, tourism policymakers are more concerned about creating economic growth and development (Özdemir et al., 2014; Wickens et al., 2014) than environmental, social or cultural growth and development of tourism product.

Disbalance of aims within tourism policy could generate some problems in destination product. It is particularly important to establish the balance between economic and environmental objectives (Hadjikakou et al., 2015; Ritchie, Crouch, 2009), but also between economic and cultural, ecological and cultural, and social and cultural aims in the destination. Focus in this study is to establish a balance between economic, ecological and social aims on the one hand, and cultural aims on the other hand. 
Cultural tourism is a based on participation in a cultural experience in tourism (Kantarci et al., 2015; Remoaldo et al., 2014; Tomljenović, 2006). It is selective tourism type with good tourism development potential (Guedes, Jiménez, 2015; Saarinen, 2016; Stratan et al., 2015) and strong economic impact on tourism destination (Baud, Ypelj, 2009; Torre, Scarborough, 2017). It is the main reason why tourism policymakers should focus on creating cultural tourism policy. Today, cultural tourism policy exists in many tourism destinations (De Esteban Curiel, Antonovica, Idoeta, 2012; Raj, 2013), and policymakers should create measures and activates for improving cultural tourism development in the destination. It is a very hard job and a job that will be done by professionals in the field of cultural tourism policy.

Tourism policy could accelerate or decline regional development of tourism (Goh, Li, Zhang, 2015; Williams, 2009), i.e., regional development of cultural tourism. Nowadays, from that aspect, regional tourism policy is very popular which can be a focus on the development of regional tourism product (Hottola, 2009; Nicula et al., 2013), i.e., cultural tourism product. That includes usage of regional tourism resource (Chen et al., 2015; Du Rand, Heath, 2006; Peters et al., 2011), i.e., regional cultural tourism resource.

This study tries to find the interdependence between measure and activities of tourism policy on the one hand and regional affiliation of employees on the other hand. The aim is to find possible significant differences in the regional affiliation of employees' perception of the importance of measures and activities in tourism policy concerning the growth and development of the cultural tourism in Montenegro.

\section{Methodology}

Employees in the sector of cultural tourism in Montenegro were participants (employees in heritage hotels, museums, specialized travel agencies and tourism organizations). A sample size of $\mathrm{n}=746$ includes 61.1 percent of female and 38.9 percent of male respondents. The share of respondents by regional affiliation is 57.8 percent of respondents from the coastal region, 32.8 percent of respondents from the central region, and 9.4 percent of respondents from the northern region.

Table 1. Independent variables

\begin{tabular}{|l|l|}
\hline Variables & Description of the variable \\
\hline IV-1 & The law on tourism \\
\hline IV-2 & The law on tourism organizations \\
\hline IV-3 & The law on tourist tax \\
\hline IV-4 & The law on the ski slopes \\
\hline IV-5 & The law on mountain trails \\
\hline IV-6 & The law on rafting \\
\hline IV-7 & The law on nature protection \\
\hline IV-8 & The law on the management of wastewater \\
\hline IV-9 & The law on inspection control \\
\hline IV-10 & The law on national parks \\
\hline IV-11 & The regulation on records of tourist traffic \\
\hline IV-12 & The regulation of sport and adventure activities \\
\hline
\end{tabular}




\begin{tabular}{|l|l|}
\hline Variables & Description of the variable \\
\hline IV-13 & The regulation on the classification and categorization of water \\
\hline IV-14 & The regulations on keeping the guest list \\
\hline IV-15 & The rules on the arrangement of baths \\
\hline IV-16 & The rules on wellness tourism \\
\hline IV-17 & The decision on the revision of the Masterplan of Montenegro \\
\hline IV-18 & The decision on establishment of the Council for sustainable development of tourism \\
\hline IV-19 & The strategy for tourism development of Montenegro \\
\hline IV-20 & The nautical tourism development strategy \\
\hline IV-21 & The spatial plan of Montenegro \\
\hline IV-22 & The spatial plan for specific types of selective tourism \\
\hline IV-23 & The promotion of Montenegro as a tourist destination \\
\hline IV-24 & The promotion of certain types of selective tourism \\
\hline IV-25 & The privileged credit lines for investment in hotels 4* and 5* \\
\hline IV-26 & The privileged lines of credit for entrepreneurial activities in the field of selective tourism \\
\hline IV-27 & The reduction of contributions for new employees in the tourism sector \\
\hline IV-28 & The tax cuts for organizations in the field of health tourism \\
\hline IV-29 & The reduction of customs tariff on imports of equipment and services for the hotel industry \\
\hline IV-30 & The reduction of customs tariff on imports of equipment and services in the field of ecotourism \\
\hline IV-31 & The retraining of unemployed for the needs of the tourism sector \\
\hline IV-32 & The education of the workforce for the purposes of adventure tourism \\
\hline
\end{tabular}

Source: Compiled by the authors

The dependent variable is a regional affiliation of employees (RA). Respondents could answer the question "In which region do you work?" choosing the northern region ( 1 1), the central region $\left(\mathrm{R}_{2}\right)$ or the coastal region $\left(\mathrm{R}_{3}\right)$. Data were analyzed by IBM SPSS software (Field, 2009), and by using statistical procedures factor analysis and multivariate analysis of variance (Lopez-Bonilla, Lopez-Bonilla, 2014). The main aim is to explore whether there is a difference between regional affiliations of employees and employees' perception of tourism policy in the sector of cultural tourism in Montenegro. Hypothesis 1 - There are significant differences in the employees' perception of the importance of measures and activities of tourism policy in the cultural tourism, using regional affiliation of respondents. However, that difference could not significantly influence tourism policymaking process and the quality of specific tourism policy, which is intended for development of cultural tourism in Montenegro.

\section{Results}

Results of Bartlett's test of sphericity are Kaiser-Meyer-Olkin measure of sampling adequacy = 0.956; Approx. Chi-square $=18217.751 ; \mathrm{df}=496$; and Sig. $=$. ooo. Positive results of previous enabled using other statistical procedures. Total initial eigenvalues values suggest using components $\mathrm{F}_{1}$ (15.146), F2 (2.438), F3 (1.798), $\mathrm{F}_{4}$ (1.129), and $\mathrm{F}_{5}$ (1.009), in the next statistical procedures.

Cattell's diagram points on components $\mathrm{F}_{1}, \mathrm{~F}_{2}, \mathrm{~F}_{3}$, and $\mathrm{F}_{4}$, and factor matrix points on components $\mathrm{F}_{1}, \mathrm{~F}_{2}, \mathrm{~F}_{3}, \mathrm{~F}_{4}$, and $\mathrm{F}_{5}$. Comparison of the characteristic value obtained by principal components analysis methodology (with parallel analysis methodology) points to accept components 
$F_{1}, F_{2}$, and $F_{3}$. The main factor's weight for components: $F_{1}$ give the items $F_{22}, F_{21}, F_{18}, F_{19}$ and $\mathrm{F}_{17} ; \mathrm{F}_{2}$ give the items $\mathrm{F}_{5}, \mathrm{~F}_{4}, \mathrm{~F} 6, \mathrm{~F}_{10}$ and $\mathrm{F}_{13} ; \mathrm{F}_{3}$ give the items $\mathrm{F}_{2}, \mathrm{~F}_{1}, \mathrm{~F}_{3}, \mathrm{~F}_{19}$, and $\mathrm{F}_{23}$; $\mathrm{F}_{4}$ give the items $F_{30}$, F29, $F_{28}$, F26, and $F_{25}$; and $F_{5}$ gives the items $F_{15}, F_{16}, F_{13}, F_{12}$, and $F_{20}$. In the further research, it is necessary to use dependent variables IV-1, IV-2, IV-3, IV-4, and IV-5.

Needed minimum sample size with the middle impact of sample size on research results for F tests (Doane, Seward, 2011) and multivariate analysis of variance determine Pillai $\mathrm{V}=$ 0.25 , Effect size $\mathrm{f}_{2}(\mathrm{~V})=0.1428571, \alpha$ error prob. $=0.05$, Power $=0.8 \mathrm{o}$ is $\mathrm{n}=141$. The sample size in this survey is five times more than the needed minimum.

Table 2. Descriptive

\begin{tabular}{|c|c|c|c|c|c|c|}
\hline Variables & Mean & Trimmed Mean & Variance & Std. Deviation & Skewness & Kurtosis \\
\hline IV-1 & 1.2426 & 1.2979 & 0.573 & 0.75714 & -0.901 & 0.988 \\
\hline IV-2 & 1.1595 & 1.2175 & 0.682 & 0.82577 & -0.863 & 0.746 \\
\hline IV-3 & 1.0375 & 1.1107 & 0.785 & 0.88610 & -0.828 & 0.590 \\
\hline IV-4 & 0.4853 & 0.5392 & 1.308 & 1.14361 & -0.455 & -0.454 \\
\hline IV-5 & 0.5389 & 0.5987 & 1.366 & 1.16859 & -0.519 & -0.466 \\
\hline
\end{tabular}

Source: Compiled by the authors

Results from the table 1 indicate that there is no extreme value in the sample. The assumption of normality of distribution is violated. That is usual for the research in the field of social science. Using Kolmogorov-Smirnov test the minimum value of the maximum deviation for this sample with significant level of alpha .01 is .06o. For Kolmogorov-Smirnov test results are for IV-1 $=0.249, I_{-2}=0.234, I_{-3}=0.247, I_{-5}=0.194$, and IV-5 $=.200$, and for Shapiro-Wilk test results are for IV-1 $=0.792, \mathrm{IV}_{-2}=0.813, \mathrm{IV}-3=0.835, \mathrm{IV}_{-5}=0.895$, and IV-5 $=.889$. Each value has Sig. $=.000$. The assumption of normality of data distribution is partially violated.
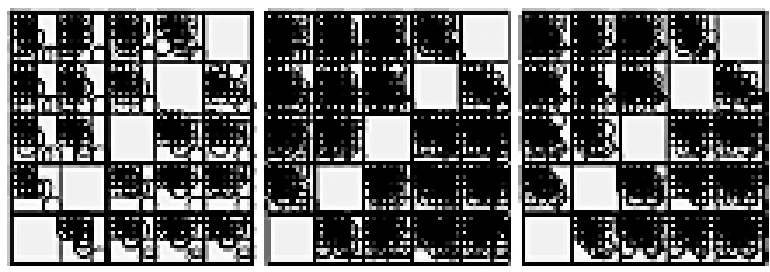

Figure 1. Matrix scatter plot of independent variables by regional affiliation of employees Source: Compiled by the authors

Sample size has no untypical points, and results from figure 2 indicate that linearity of the variable is fulfilled. Out of the total number of Spearman correlation, 20 percent is a small correlation, 40 percent is a medium correlation, and 40 percent is a high correlation according to Cohen criteria. The non-variable combination has a value less than 0.200 . Only the correlation between IV-4 and IV-5 is higher than $0.800(\mathrm{r}=.879)$.

The results of Box's test have shown that Box's $M=143.019, \mathrm{~F}=4.683, \mathrm{df}_{1}=30, \mathrm{df}_{2}=$ 136142.560 , and Sig. $=.000$. Levene's test of equality of error variances has shown that IV-1 has Sig. $=0.747$, IV-2 has Sig. $=0.124$, IV -3 has Sig. $=0.552$, IV-4 has Sig. $=0.140$, and IV -5 has Sig. $=0.018$. Robust test of equality of means has shown that only IV -5 has Welch value with Sig. $=$ .000 and Brown-Forsythe value with Sig. $=.000$. The assumption of homogeneity of matrix of variance and covariance is partially violated. 
Table 3. Multivariate tests

\begin{tabular}{|c|c|c|c|c|c|c|c|}
\hline Effect & & Value & F & $\begin{array}{c}\text { Hypothesis } \\
\text { df }\end{array}$ & Error df & $\begin{array}{c}\text { Sig. } \\
\text { Sartial Eta } \\
\text { Squared }\end{array}$ \\
\hline Intercept & Pillai's Trace & .627 & 247.991 & 5.000 & 739.000 & .000 & .627 \\
\hline RA & Pillai's Trace & .042 & 3.149 & 10.000 & 1480.000 & .001 & .021 \\
\hline
\end{tabular}

Source: Compiled by the authors

There is a difference in employees' perception of the importance of measures and activities in tourism policy by regional affiliation. Table 2 does not show which regions and what is the level of that influence between regions.

Table 4. Tests of between-subjects' effects

\begin{tabular}{|c|c|c|c|c|c|c|c|}
\hline Source & $\begin{array}{c}\text { Dependent } \\
\text { Variables }\end{array}$ & $\begin{array}{c}\text { Type III Sum } \\
\text { of Squares }\end{array}$ & df & Mean Square & F & Sig. & $\begin{array}{c}\text { Partial Eta } \\
\text { Squared }\end{array}$ \\
\hline RA & IV-1 & 3.466 & 4 & .867 & 1.516 & .196 & .008 \\
\hline & IV-2 & 4.604 & 4 & 1.151 & 1.694 & .149 & .009 \\
\hline & IV-3 & 2.940 & 4 & .735 & .936 & .443 & .005 \\
\hline & IV-4 & 17.563 & 4 & 4.391 & 3.401 & .009 & .018 \\
\hline
\end{tabular}

Source: Compiled by the authors

The result in table 3 is significant for dependent variable IP-5. Regional affiliation of employees explains 2.1 percent of the variance in the results of measuring employees' perception of the importance of the law on mountain trails.

\section{Discussion}

In the process of allocating factor it were used Bartlett's Test of Sphericity, Cattell's diagram, Principal Components Analysis methodology (with parallel analysis methodology), Rotation with direct Oblimin with Kiser's normalization, it was very clear that it is necessary to use dependent variables: The law on tourism; The law on tourism organizations; The law on tourist tax; The law on the ski slopes; and The law on mountain trails.

Using the Bonferroni's method of adjustment (Field, 2009), the main significant differences are less than .010. In employees' perception of measures and activities of tourism policy in the sector of cultural tourism, a significant difference was manifested between interviewed employees from the northern and the coastal region $(\mathrm{MD}(\mathrm{I}-\mathrm{J})=0.57309, \mathrm{SD}=0.14920$, Sig. $=$ .ooo) about the law on mountain trails. A significant difference was shown between the less developed and the most developed region of cultural tourism in Montenegro.

The research result, between the northern and the coastal region, is significant for many reasons. Firstly, about 70 percent of total immobile cultural heritage is located in the coastal region, specifically in the bay of Boka Kotorska and old town of Kotor. The least percent of total immobile cultural heritage is located in the northern region. The situation is similar to mobile cultural heritage in Montenegro.

Secondly, the coastal region is the most developed touristic region while the northern region is the least developed touristic region in Montenegro. The coastal region has better 
tourism infrastructure for every type of selective tourism, including cultural tourism. The northern region has in number and quality the very weak human resource capacity for cultural tourism development, and the coastal region has the strongest human resource capacity. The problem could be in the transport approach because the coastal region has the best transport approach for tourists, while the northern region has the worst transport approach for tourists in Montenegro.

\section{Conclusion}

Cultural tourism is the leading selective tourism type at the global tourism market. It is the main selective tourism type even in Montenegro. In the international context, there is an insufficient number of articles dealing with the research of the relationship between the individual social characteristic of employees (from institutions and organizations of cultural tourism) and the measures and activities of the tourism policy. This study tries to explain whether there is a difference between regional affiliations of employees and employees' perception of tourism policy in the sector of cultural tourism in Montenegro.

The main factor's weight for the law on mountain trails gave dependent variables: the rules on the arrangement of baths, the rules on wellness tourism, the regulation on the classification and categorization of water, the regulation on sport and adventure activities, and the nautical tourism development strategy. The significant difference is not manifested in measures and activities of tourism policy, which directly influenced the growth and development of cultural tourism, for two basic reasons.

Interviewed employees in heritage hotels, museums, specialized travel agencies and tourism organizations do not know so much about tourism policy, specifically about measures and activities that directly influenced the growth and development of cultural tourism. Only independent variable "spatial plan for specific types of selective tourism" is the measure that directly influenced the growth and development of cultural tourism in Montenegro. However, what do the employees know about differences between the different type of selective tourism and about spatial planning? The study has shown that regional affiliation is not yet an important variable that tourism policymakers use in creating a process of measures and activities of tourism policy for accelerating the growth and development of cultural tourism in Montenegro.

Research limitation is that the sample size was conducted in Montenegro as a transitional and small tourism destination, and that results could be different in huge and developed tourism destination of cultural tourism, specifically in a destination where tourism policy consists of many measures and activities that directly influenced the growth and development of cultural tourism. Theoretical implication is the necessity of development of more specific measures and activities that could help policymakers to improve cultural tourism. The practical implication is that regional affiliation influences employees' perception of the importance of measures and activities of tourism policy significantly, but that difference could not significantly influence tourism policymaking process and the quality of specific tourism policy, which is intended for development of cultural tourism sector. Recommendation for future research is to use more specific measures and activities of tourism policy, which directly influence the growth and development of cultural tourism. 


\section{Acknowledgement}

We would like to express our gratitude to Erasmus+ CULTURWB project and European Commission.

\section{References}

Adamczyk, B. 2005. The National Tourism Organisations of Poland, the Czech Republic, Slovakia and Hungary - the organisation and activities. Tourism: An International Interdisciplinary Journal 53(3), 247-258.

Andriotis, K. 2004. European Union influence over tourism employment. Tourism: An International Interdisciplinary Journal 52(3), 277-284.

Baud, M., Ypelj, A. 2009. Cultural Tourism in Latin America: The Politics of Space and Imagery. London: Brill.

Boniface, B., Cooper, C. 2009. Worldwide Destinations: The Geography of Travel and Tourism (5 ed.). Oxford: Butterworth-Heinemann.

Camisón, C., Forés, B. 2015. Is tourism firm competitiveness driven by different internal or external specific factors?: New empirical evidence from Spain. Tourism Management 48, 477-499.

Castillo-Manzano, J. I. 2010. Determinants of commercial revenues at airports: Lessons learned from Spanish regional airports. Tourism Management 31(6), 788-796.

Chen, A., Lu, Y., Ng, Y. C. Y. 2015. The Principles of Geotourism. New York: Springer.

Čorak, S., Mikačić, V. 2006. Hrvatski turizam: plavo-bijelo-zeleno. Zagreb: Institut za turizam.

De Esteban Curiel, J., Antonovica, A., Idoeta, C. M. 2012. Critical Factors and Consumption Patterns of Pergamon Museum's Visitors (Berlin, Germany). Procedia - Social and Behavioral Sciences 65, 313-320.

Doane, D. P., Seward, L. E. 2011. Applied Statistics in Business and Economics (3 ed.). New York: The McGraw-Hill Companies, Inc.

Du Rand, G. E., Heath, E. 2006. Towards a Framework for Food Tourism as an Element of Destination Marketing. Current Issues in Tourism 9(3), 206-234.

Edgell, D. L., Allen, D. M., Swanson, J. R. 2008. Tourism Policy and Planning: Yesterday, Today and Tomorrow. Oxford: Butterworth-Heinemann.

Estol, J., Font, X. 2016. European Tourism Policy: Its Evolution and Structure. Tourism Management 52, 230-241.

Field, A. 2009. Discovering Statistics Using SPSS (3 ed.). SAGE Publications Ltd.: London.

Goh, C., Li, H., Zhang, Q. 2015. Achieving balanced regional development in China: is domestic or international tourism more efficacious? Tourism Economics 21(2), 369-386.

Guedes, A. S., Jiménez, M. I. M. 2015. Spatial patterns of cultural tourism in Portugal. Tourism Management Perspectives 16, 107-115.

Hadjikakou, M., Miller, G., Chenoweth, J., Druckman, A., Zoumides, C. 2015. A comprehensive framework for comparing water use intensity across different tourist types. Journal of Sustainable Tourism 23(10), 1445-1467.

Hai-ling, G., Liang-qiang, W., Yong-Peng, L. 2011. A GIS-based approach for information management in ecotourism region. Procedia Engineering 15, 1988-1992.

Hall, D., Smith, M., Marciszewska, B. 2006. Tourism in the New Europe: The Challenges and Opportunities of EU Enlargement. Wallingford: CAB International. 
Horng, J.-S., Tsai, C.-T. 2010. Government websites for promoting East Asian culinary tourism: A cross-national analysis. Tourism Management 31(1), 74-85.

Hottola, P. 2009. Tourism Strategies and Local Responses in Southern Africa. Wallingford: $\mathrm{CAB}$ International.

Jeuring, J. H. G., Haartsen, T. 2016. The challenge of proximity: the (un)attractiveness of nearhome tourism destinations. Tourism Geographies 1-24.

Kantarci, K., Uysal, M., Magnini, V. 2015. Tourism in Central Asia: Cultural Potential and Challenges. Toronto: Apple Academic Press.

Lee, S., Bai, B. 2016. Influence of Popular Culture on Special Interest Tourists' Destination Image. Tourism Management 52, 161-169.

Lopez-Bonilla, J. M., Lopez-Bonilla, L. M. 2014. Current Issues in Method and Practice. Holistic competence approach in tourism higher education: an exploratory study in Spain. Current Issues in Tourism 17(4), 312-326.

Luković, T. 2013. Nautical Tourism. Wallingford: CAB International.

Matias, Á., Nijkamp, P., Sarmento, M. 2009. Advances in Tourism Economics: New Development. London: Physical-Verlag Heidelberg.

McKercher, B. 2005. How Special Is Special Interest Tourism? Journal of Travel Research, 44(1), 21-31.

Moufakkir, O., Burns, P. M. 2012. Controversies in Tourism. Wallingford: CAB International.

Nicula, V., Spânu, S., Neagu, R. E. 2013. Regional Tourism Development in Romania - Consistency with Policies and Strategies Developed at EU Level. Procedia Economics and Finance 6, 530-541.

Novelli, M. 2005. Niche Tourism: Contemporary Issues, Trends and Cases. Oxford: Butterworth-Heinemann.

Özdemir, G., Yilmaz, M., Yalçin, M., Alvarez, M. D. 2014. Stakeholders' Perception of Istanbul's Historical Peninsula as a Sustainable Destination. Tourism Planning \& Development 12(1), 87-98.

Pasinović, M. 2006. Menadžment prirodnih i kulturnih resursa. Bar: Fakultet za turizam, hotelijerstvo i trgovinu.

Peters, M., Siller, L., Matzler, K. 2011. The resource-based and the market-based approaches to cultural tourism in alpine destinations. Journal of Sustainable Tourism 19(7), 877-893.

Raj, R. 2013. Cultural Tourism. Wallingford: CAB International.

Ranjan Debata, B., Sree, K., Patnaik, B., Sankar Mahapatra, S. 2013. Evaluating medical tourism enablers with interpretive structural modeling. Benchmarking: An International Journal 20(6), 716-743.

Remoaldo, P. C., Ribeiro, J. C., Vareiro, L., Santos, J. F. 2014. Tourists' perceptions of world heritage destinations: The case of Guimaraes (Portugal). Tourism and Hospitality Research 14(4), 206-218.

Ritchie, J. R. B., Crouch, G. I. 2009. The Competitive Destination: A Sustainable Tourism Perspective. Wallingford: CAB International.

Saarinen, J. 2016. Cultural tourism and the role of crafts in Southern Africa: The case of craft markets in Windhoek, Namibia. Tourism: An International Interdisciplinary Journal 64.(4), $409-418$.

Stratan, A., Perciun, R., Gribincea, C. 2015. Identifying Cultural Tourism Potentials in Republic of Moldova through Cultural Consumption among Tourists. Procedia - Social and Behavioral Sciences 188, 116-121. 
Thomas, R., Thomas, H. 2006. Micro politics and micro firms: a case study of tourism policy formation and change. Journal of Small Business and Enterprise Development 13(1), 100-114.

Tomljenović, R. 2006. Kulturni turizam. In S. Čorak \& V. Mikačić (Eds.), Hrvatski turizam: plavo-bijelo-zeleno (pp. 119-147). Zagreb: Institut za turizam.

Torre, A., Scarborough, H. 2017. Reconsidering the estimation of the economic impact of cultural tourism. Tourism Management 59, 621-629.

VRCG 2008. Strategija razvoja turizma Crne Gore do 2020. godine. Podgorica: Vlada Republike Crne Gore.

Vučetić, A. Š. 2017. Influence of Job Stability on Employees' Perception about Importance of Concrete Measures and Activities of Tourism Policy in the Destination of Cultural Tourism. International Scientific Journal - TURIZAM 21(2), 81-89.

Vuleković, T. N. 2009. Kultura i turizam. Cetinje: Obod.

Wickens, E., Bakir, A., Alvarez, M. D. 2014. Sustainable Destination Development: Issues and Challenges. Tourism Planning \& Development 12(1), 1-5.

Williams, S. 2009. Tourism Geography: A new Synthesis (2 ed.). New York: Routledge. 